\author{
Lila Abu-Lughod \\ Universidade de Columbia
}

\title{
As mulheres muçulmanas precisam realmente de salvação? Reflexões antropológicas sobre o relativismo cultural e seus Outros
}

\begin{abstract}
Resumo: Este artigo explora a ética da atual "Guerra ao Terrorismo", perguntando se a antropologia, disciplina dedicada a entender a diferença cultural e a lidar com ela, pode nos fornecer apoio crítico para as justificações feitas sobre a intervenção no Afeganistão em termos de liberar ou salvar mulheres afegãs. Eu observo primeiramente os perigos da cultura de reificação, aparente nas tendências de afixar ícones culturais claros como as mulheres muçulmanas sobre confusas dinâmicas históricas e políticas. Posteriormente, chamando atenção para as ressonâncias entre discursos contemporâneos sobre igualdade, liberdade e direitos com antigos discursos coloniais e retórica missionária sobre mulheres muçulmanas, eu argumento que, em vez disso, nós precisamos desenvolver uma séria avaliação das diferenças entre as mulheres no mundo - como produtos de histórias diferentes, expressões de diferentes circunstâncias e manifestações de desejos distintamente estruturados. Além disso, eu argumento que, em vez de buscar "salvar" outros (com a superioridade que isso implica e as violências que acarretaria), talvez fosse melhor pensarmos em termos de (1) trabalhar com elas nas situações que reconhecemos como sempre sujeitas a transformações históricas e (2) considerar nossas próprias e maiores responsabilidades para indicar as formas de injustiça global que são poderosas formadoras dos mundos nas quais elas se encontram. Eu desenvolvo muito desses argumentos a respeito dos limites do "relativismo cultural" através de uma consideração da burca e dos vários significados dos véus no mundo muçulmano.
\end{abstract}

Palavras-chave: relativismo cultural; mulheres muçulmanas; guerra no Afeganistão; liberdade; injustiça global; colonialismo.

Copyright () 2012 by Revista Estudos Feministas.

1 Este artigo foi publicado pela American Anthropologist, v. 104, n. 3, p. 783-790, 2002. Tradução de João Henrique Amorim, bacharel em Ciências Sociais, UnB (jhbamorim@yahoo.com) e revisão da tradução por Soraya
Qual é a ética da atual "Guerra ao Terrorismo", uma guerra que se justifica por ter o sentido de liberar ou salvar mulheres afegãs?' A antropologia possui algo a oferecer em nossa busca por uma posição viável a assumir em relação a essa base lógica para a guerra?

Eu fui levada a questionar meu título em parte por causa da forma com que eu pessoalmente experimentei a 
Fleischer, professora do Departamento de Antropologia, UnB (soraya_fleischer@yahoo.com.br).

${ }^{2}$ Ver William SAFIRE, 2001. resposta à guerra americana no Afeganistão. Como muitos colegas cujo trabalho focou-se em mulheres e gênero no Oriente Médio, eu fui inundada com convites para falar não apenas em programas de notícias, mas também para vários departamentos em faculdades e universidades, especialmente programas de estudos femininos. Por que isso não me agradou, uma estudiosa que devotou mais de 20 anos de sua vida a esse assunto e que teve algumas conexões pessoais complicadas com sua identidade? Aqui estava uma oportunidade de espalhar a palavra, disseminar meu conhecimento e corrigir más interpretações. A busca urgente por conhecimento a respeito de nossas irmãs "mulheres de cobertura" (como o presidente George Bush tão maravilhosamente as chamou) é louvável quando vem de programas de estudo feminino nos quais "feminismo transnacional" está agora sendo levado a sério, tem certa integridade. $^{2}$

Meu desconforto me levou a refletir sobre o porquê, como feministas no ou do Ocidente, ou simplesmente como pessoas que possuem preocupações sobre a vida das mulheres, nós precisamos estar atentos para essa resposta aos eventos e resultados do 11 de setembro de 2001. Eu quero apontar os campos minados - uma metáfora que é infelizmente muito adequada para um país como o Afeganistão, com o maior número de minas per capita - dessa obsessão com o sofrimento das mulheres muçulmanas. Eu espero mostrar algum caminho através delas utilizando conhecimentos da antropologia, a disciplina cuja incumbência tem sido entender e gerenciar diferenças culturais. Ao mesmo tempo, eu quero permanecer crítica da cumplicidade da antropologia na reificação da diferença cultural.

\section{Explicações culturais e a mobilização das mulheres}

É mais fácil ver por que se deveria ser cético a respeito do foco na "mulher muçulmana" se se começa com a resposta pública dos Estados Unidos. Eu analisarei duas manifestações dessa resposta: algumas conversas que eu tive com uma repórter do PBS News Hour, com Jim Lehrer, e o discurso no rádio da primeira-dama, Laura Bush, dirigido à nação em 17 de novembro de 2001. O apresentador do programa News Hour me contatou inicialmente em outubro para ver se eu desejaria dar algum segundo plano para um segmento a respeito de mulheres e o Islã. Eu maliciosamente perguntei se ela havia feito segmentos sobre as mulheres da Guatemala, da Irlanda, da Palestina ou da Bósnia quando o programa cobria guerras nessas regiões; mas eu finalmente concordei em olhar as questões que ela iria 
submeter aos participantes da mesa-redonda. As questões eram desesperadoramente generalistas. As mulheres muçulmanas acreditam em ' $x$ '? As mulheres muçulmanas são ' $y$ '? O Islã permite 'z' para as mulheres? Eu perguntei: se você fosse substituir por "cristãs" ou "judias" todos os lugares onde aparece "muçulmanas", essas questões fariam sentido? Eu não imaginei que ela fosse me ligar novamente. Mas ela ligou duas vezes, uma vez com uma ideia para um segmento sobre o significado do Ramadã e outra vez sobre mulheres muçulmanas na política. Uma foi em resposta ao bombardeio e outra aos discursos de Laura Bush e Cherie Blair, esposa do primeiro-ministro britânico.

O que é admirável sobre essas duas ideias para programas de notícias é que havia um recurso consistente ao cultural, como se sabendo algo a respeito de mulheres e do Islã ou o significado de um ritual religioso fosse ajudar a entender o trágico ataque ao World Trade Center em Nova York e ao Pentágono, ou como o Afeganistão veio a ser dominado pelo Talibã, ou quais interesses moveram os Estados Unidos e outras intervenções na região durante os últimos 25 anos, ou o que deve ter sido a história do apoio americano a grupos conservadores com o fundamento de minar os soviéticos, ou porque as cavernas e as casamatas das quais Bin Laden deveria forçosamente ser retirado "vivo ou morto", como o presidente Bush anunciou na televisão, foram pagas e construídas pela CIA.

Em outras palavras, a questão é por que saber sobre a "cultura" da região e particularmente suas crenças religiosas e o tratamento dispensado às mulheres era mais urgente do que explorar a história e o desenvolvimento dos regimes repressivos na região e o papel dos Estados Unidos nessa história. Tal enquadramento cultural, me pareceu, obstava a exploração séria das raízes e da natureza do sofrimento humano nessa parte do mundo. Em vez de explicações políticas e históricas, solicitavam-se dos especialistas explicações culturais. Em vez de questões que talvez levassem à exploração das interconexões globais, ofereceram-nos outras que serviam para artificialmente dividir o mundo em esferas separadas - recriando uma geografia imaginária do Ocidente em oposição ao Oriente, nós em oposição aos muçulmanos, culturas nas quais primeiras-damas dão discursos em oposição a outras nas quais as mulheres andam contidas e silenciosas em burcas.

Mais premente para mim era por que as mulheres muçulmanas em geral, e as afegãs em particular, eram tão cruciais para esse modo cultural de explicação, o qual ignorava o complexo enredo no qual todos estamos envolvidos, em alinhamentos algumas vezes surpreendentes. Por que esses símbolos femininos foram mobilizados nessa 
3 Laura Bush citada por U.S. GOVERNMENT, 2002.

${ }^{4}$ Gayatri Chakravorty SPIVAK, 1988.

${ }^{5}$ Leila AHMED, 1992.
"Guerra contra o Terrorismo" de uma forma que eles não foram em outros conflitos? O discurso de rádio que Laura Bush dirigiu à nação em 17 de novembro revela o trabalho político que tal mobilização efetua. Por um lado, seu discurso arruinou distinções importantes que deveriam ter sido mantidas. Havia um constante deslizamento entre o Talibã e os terroristas, de forma que eles quase se tornaram uma única palavra - um tipo de identidade de monstro hifenizada: o talibã-e-os-terroristas. Depois havia o obscurecimento das bem separadas causas, no Afeganistão, da continuada desnutrição feminina, pobreza e saúde precária, e sua mais recente exclusão, sob o Talibã, do emprego, da educação e das alegrias de utilizar esmalte de unha. Por outro lado, seu discurso reforçava algumas divisões abismais, primariamente entre os "povos civilizados pelo mundo" cujos corações se partiam pelas mulheres e pelas crianças do Afeganistão e os talibãs-e-os-terroristas, os monstros culturais que querem, como mencionou, "impor seus mundos sobre o resto de nós".

De forma mais esclarecedora, o discurso angariava mulheres para justificar o bombardeio americano e a intervenção no Afeganistão e para defender a "Guerra ao Terrorismo" do qual ela era supostamente uma parte. Como disse Laura Bush,

Por causa de nossos recentes ganhos militares em boa parte do Afeganistão, as mulheres não mais estão aprisionadas em suas casas. Elas podem ouvir música e ensinar suas filhas sem medo de punição. A luta contra o terrorismo é também uma luta pelos direitos e dignidade das mulheres. ${ }^{3}$

Essas palavras têm ressonâncias assombrosas para qualquer um que estudou história colonial. Muitos que trabalharam com colonialismo britânico no sul asiático notaram o uso da questão feminina nas políticas coloniais em que intervenção no sati (a prática de viúvas de se autoimolarem nas piras funerárias de seus maridos), casamento infantil e outras práticas foram usados para justificar o domínio. Como Gayatri Chakravorty Spivak ${ }^{4}$ cinicamente colocou: homens brancos salvando mulheres marrons de homens marrons. O registro histórico é cheio de casos similares, inclusive no Oriente Médio. Em Women and Gender in Is/am, o que Leila Ahmed ${ }^{5}$ chamou de "feminismo colonial" estava firmemente funcionando. Essa era uma preocupação seletiva a respeito da situação das mulheres egípcias que focava no véu como um signo de opressão, mas não dava qualquer apoio à educação feminina e era professada em alta voz pelo mesmo inglês, Lord Cromer, que se opusera ao sufrágio feminino em seu país. 
${ }^{6}$ Marnia LAZREG, 1994, p. 135.

${ }^{7}$ LAZREG, 1994, p. 68-69.
A socióloga Marnia Lazreg ${ }^{6}$ ofereceu alguns exemplos vívidos de como o colonialismo francês angariou mulheres para sua causa na Argélia. Ela escreve:

Talvez o mais espetacular exemplo de apropriação colonial das vozes femininas e o silenciamento daquelas entre elas que tinham começado a tomar mulheres revolucionárias... como papéis modelo por não vestir o véu, foi o evento de 16 de maio de 1958 [apenas quatro anos antes de a Argélia finalmente ganhar sua independência da França depois de um longo conflito sangrento e 130 anos de controle francês]. Naquele dia a demonstração foi organizada por generais franceses sublevados em Argel para mostrar a determinação deles de manter a Argélia francesa. Para dar ao governo da França evidência de que argelinos estavam de acordo com eles, os generais arranjaram alguns milhares de homens nativos, levados de ônibus das vilas próximas até o local, junto com algumas mulheres das quais o véu foi solenemente retirado por mulheres francesas. Arrebanhar argelinos e trazê-los para demonstrações de lealdade à França não era em si um ato incomum durante a era colonial. Mas retirar o véu de mulheres numa tão bem coreografada cerimônia acrescentou ao evento uma dimensão simbólica que dramatizava a característica constante da ocupação argelina pela França: sua obsessão com as mulheres.

Lazreg7 também dá exemplos memoráveis da forma pela qual os franceses tinham anteriormente buscado transformar mulheres e garotas árabes. Ela descreve cenas de cerimônias na Escola Muçulmana de Garotas, na Argélia, em 1851 e 1852. Na primeira cena, escrita por "uma dama francesa da Argélia", duas garotas árabes argelinas recordam sua viagem para a França com palavras que incluíam o seguinte:

Oh! Protetora França! Oh! Hospitaleira França!... Nobre terra, onde me senti livre Sob céus cristãos para rezar ao nosso Deus...

Deus os abençoe pela felicidade que nos trazem! E você, mãe adotiva, que nos ensinou Que nós temos uma porção desse mundo, Nós a estimaremos para sempre!

Faz-se com que essas garotas invoquem a dádiva de uma porção desse mundo, um mundo onde a liberdade reina sob os céus cristãos. Esse não é o mundo que o talibãe-os-terroristas "gostariam de impor ao resto de nós".

Tal como argumentei acima que precisamos suspeitar quando nítidos ícones culturais são afixados sobre narrativas políticas e históricas mais desordenadas, também 
precisamos estar alerta quando Lord Cromer no Egito sob domínio britânico, damas francesas na Argélia e Laura Bush, com todas as tropas militares detrás deles, clamam estar salvando ou libertando mulheres muçulmanas.

\section{Política do véu}

Eu quero olhar agora mais de perto aquelas mulheres afegãs que Laura Bush afirmou estarem "regozijantes" por sua liberação pelos americanos. É necessária uma discussão acerca do véu, ou da burca, porque isso é muito central para as preocupações contemporâneas sobre as mulheres muçulmanas. Isso lançará o palco para uma discussão sobre como antropólogas, as feministas em particular, discutem o problema da diferença em um mundo globalizado. Na conclusão, retornarei à retórica de salvar mulheres muçulmanas e oferecerei uma alternativa.

É sabedoria popular comum que o sinal mais significativo da opressão das mulheres afegãs sob o regime do Talibã e dos terroristas é que elas são forçadas a vestir a burca. Os liberais às vezes confessam sua surpresa em relação ao fato de que, apesar de o Afeganistão ter sido liberado do Talibã, as mulheres parecem não estar jogando fora as suas burcas. Alguém que trabalhou em regiões muçulmanas deve perguntar por que isso é tão surpreendente. Esperávamos que, uma vez "livres" do Talibã, elas iriam "retornar" a camisetas curtas e jeans, ou tirar a poeira de seus trajes Chanel? Precisamos ser mais sensíveis sobre a vestimenta das mulheres cobertas, e, portanto, talvez haja necessidade de apresentar alguns pontos básicos sobre o uso do véu.

Primeiro, é preciso lembrar que o Talibã não inventou a burca. É a forma de cobertura que as mulheres pashtun em determinada região usavam quando saíam. Os pashtun são um dos diversos grupos étnicos no Afeganistão, e a burca era uma das muitas formas de vestimenta no subcontinente e no Sudoeste da Ásia que se desenvolveram como uma convenção para simbolizar a modéstia ou respeitabilidade da mulher. A burca, como algumas outras formas de "cobertura", marcou, em muitos pontos, a separação simbólica entre as esferas masculina e feminina, como uma parte da associação geral de mulheres com família e casa, e não com o espaço público onde os estranhos se misturam.

${ }^{8}$ Hanna PAPANEK, 1982.

Vinte anos atrás, a antropóloga Hanna Papanek, ${ }^{8}$ que trabalhou no Paquistão, descreveu a burca como uma "reclusão portátil". Ela notou que muitos a viam como uma invenção libertadora, porque permitia às mulheres saírem de espaços segregados ainda observando os requisitos morais básicos de separar e proteger as mulheres de homens 
com quem não se relacionavam. Desde que me deparei com sua frase "reclusão portátil", pensei em "casas móveis". Em todos os lugares, a utilização desse tipo de cobertura significa pertencimento a uma comunidade particular e participação em um modo de vida moral no qual as famílias são o centro da organização das comunidades e a casa é associada com a santidade da mulher.

A questão óbvia que segue é esta: se fosse esse o caso, por que as mulheres subitamente se tornariam não modestas? Por que elas subitamente jogariam fora a marca de sua respeitabilidade, marcas, quer burcas ou outras formas de cobertura, que servem ao propósito de assegurar sua proteção na esfera pública do assédio de homens estranhos por sinalizar simbolicamente a todos que elas ainda estavam no espaço inviolável de suas casas, ainda que se movendo no espaço público? Especialmente quando essas são formas de vestimenta que se tornaram tão convencionais que a maioria das mulheres dava pouca importância ao seu significado.

Para desenhar algumas analogias, nenhuma delas perfeita, por que estamos surpresos pelo fato de as mulheres afegãs não jogarem fora suas burcas, quando sabemos perfeitamente que não seria apropriado usar shorts em uma ópera? Na época em que estavam explodindo essas discussões sobre as burcas das mulheres afegãs, uma amiga minha foi repreendida por seu marido por sugerir que queria usar calças em um casamento chique: "Você sabe que não se vestem calças em um casamento da alta sociedade", ele lembrou. Os nova-iorquinos sabem que as belamente penteadas mulheres hassídicas, que parecem tão na moda ao lado de seus maridos de ternos e chapéus pretos, estão usando perucas. Isso ocorre porque a crença e os padrões de propriedade da comunidade requerem que o cabelo seja coberto. Elas também alteram o modelo dos vestidos para incluir golas altas e mangas compridas. Como sabem perfeitamente bem os antropólogos, as pessoas vestem a forma de roupa apropriada para suas comunidades sociais e são guiadas por padrões sociais compartilhados, crenças religiosas e ideias morais, a menos que transgridam deliberadamente para defender uma opinião ou sejam incapazes de pagar por cobertura apropriada. Se pensamos que as mulheres dos EUA vivem em um mundo de escolhas em relação à roupa, tudo o que precisamos fazer é nos lembrarmos da expressão "a tirania da moda".

O que aconteceu no Afeganistão sob o regime do Talibã é que um estilo regional de cobertura ou de uso do véu, associado a certa classe respeitável, mas não de elite, foi imposto a todos como "religiosamente" apropriado, apesar de ter havido previamente muitos estilos diferentes, 
9 Ruth FREMSON, 2001.

${ }^{10}$ Citada por FREMSON, 2001, p. 14.

1 Suzanne GOLDENBERG, 2002. populares ou tradicionais com diferentes grupos e classes diferentes formas de marcar a propriedade da mulher ou, em tempos mais recentes, a virtude religiosa. Apesar de eu não ser uma especialista em Afeganistão, eu imagino que a maioria das mulheres deixadas no Afeganistão na época em que o Talibã tomou o controle foram as da zona rural ou as menos educadas, de famílias que não eram da elite, já que foram as únicas que não puderam emigrar para escapar da dureza e da violência que marcaram a história recente do Afeganistão. Se liberadas do uso forçado da burca, a maioria dessas mulheres escolheriam alguma outra forma de cobertura modesta da cabeça, como todos aqueles vivendo próximos que não estavam sob o Talibã as suas contrapartes hindus rurais no Norte da Índia (que cobrem suas cabeças e usam véu sobre as faces na presença de desconhecidos) ou suas irmãs muçulmanas no Paquistão.

Mesmo o The New York Times veiculou um artigo sobre as mulheres afegãs refugiadas no Paquistão que tentou educar os leitores sobre essa variedade local. ${ }^{9} \mathrm{O}$ artigo descreve e ilustra tudo desde a agora icônica burca com os buracos bordados para os olhos, que uma mulher pashtun explica como sendo a vestimenta própria para a sua comunidade, até os grandes lenços que elas chamam de chadors e o novo vestido modesto islâmico que as usuárias chamam de hijab. Aquelas que usam o novo vestido islâmico são caracteristicamente estudantes objetivando carreiras profissionais, especialmente na medicina, tal como suas contrapartes do Egito à Malásia. Alguém vestindo o lenço longo era uma diretora de escola, a outra uma pobre vendedora de rua. Este é o comentário de uma jovem vendedora de rua: "Se eu usasse (a burca), os refugiados me perseguiriam porque a burca é para as 'boas mulheres' que ficam dentro de suas casas". ${ }^{10}$ Aqui você pode ver 0 status local associado à burca - é para mulheres boas e respeitáveis de famílias fortes que não são forçadas a ganhar a vida vendendo nas ruas.

O jornal britânico The Guardian publicou uma entrevista em janeiro de 2002 com a Dr.a Suheila Siddiqi, uma respeitada cirurgiã no Afeganistão que possui o grau de vice-general no corpo médico Afegão. " Uma mulher na casa dos 60, ela vem de uma família de elite e, como suas irmãs, foi educada. Ao contrário da maioria das mulheres de sua classe, ela escolheu não ir para o exílio. Ela é apresentada no artigo como "A mulher que ficou de pé frente ao Talibã" porque ela se recusou a usar a burca. Ela fez disso uma condição para retornar ao seu posto como chefe de um grande hospital quando o regime Talibã veio implorar em 1996, apenas oito meses após despedi-la juntamente 
12 e.g., Lila ABU-LUGHOD, 1995 e 1998; Suzanne BRENNER, 1996; Fadwa EL GUINDI, 1999; Arlene MACLEOD, 1991; e Aihwa ONG, 1990.

${ }^{13}$ Saba MAHMOOD, 2001. com outras mulheres. Siddiqi é descrita como magra, glamorosa e confiante. Mas mais adiante no artigo se nota que seu bufante cabelo grisalho é coberto por um véu. É um lembrete de que, embora tenha se recusado a usar a burca, ela não teve questionamentos sobre a utilização do chador ou do lenço.

Finalmente, preciso levantar um ponto crucial a respeito do uso do véu. Não apenas há muitas formas de cobertura, que têm elas mesmas significados diferentes nas comunidades nas quais são usadas, mas também o próprio uso do véu não deve ser confundido e nem usado como padrão para a falta de agência. Como argumentei em minha etnografia de uma comunidade beduína no Egito no fim dos anos 1970 e nos anos 1980 (1986), puxar o capuz negro sobre a face diante de homens mais velhos e respeitados é considerado um ato voluntário por parte das mulheres que estão profundamente comprometidas com o comportamento moral e que têm um senso de honra atado à família. Uma das formas de mostrarem sua posição é cobrir suas faces em certos contextos. Elas decidem diante de quem é apropriado usar o véu.

Para usar um caso muito diferente, o vestido modesto islâmico atual que muitas mulheres educadas têm usado pelo mundo muçulmano desde a metade da década de 1970 agora marca publicamente a devoção e pode ser visto como sinal de sofisticação urbana educada, uma espécie de modernidade. ${ }^{12}$ Como Saba Mahmood ${ }^{13}$ mostrou tão brilhantemente em sua etnografia das mulheres no movimento das mesquitas no Egito, essa nova forma de vestido também é percebida por muitas das mulheres que a adotam como parte de uma forma corporal de cultivar a virtude, o advento de seu desejo professo de estarem próximas a Deus.

Dois pontos emergem dessa discussão básica dos significados do uso do véu no mundo muçulmano contemporâneo. Primeiro, precisamos trabalhar contra a interpretação reducionista do véu como a quinta-essência dos sinais da falta de liberdade das mulheres, mesmo que nos oponhamos à imposição estatal dessa forma, como no Irã ou com o Talibã (é preciso lembrar que os estados em modernização como a Turquia e Irã tinham, no início do século, banido o uso do véu e requerido aos homens, exceto aos clérigos religiosos, que adotassem a vestimenta ocidental). $O$ que significa a liberdade se aceitarmos a premissa fundamental de que os humanos são seres sociais, sempre criados em certos contextos sociais e históricos e pertencentes a comunidades particulares que dão forma a seus desejos e entendimentos do mundo? Não é uma grande violação aos entendimentos próprios das mulheres do que 
${ }^{14}$ Marilyn STRATHERN, 1987.

${ }^{15}$ Ver Charles HIRSCKIND e Saba MAHMOOD, 2002. elas estão fazendo simplesmente denunciar a burca como uma imposição medieval? Segundo, devemos tomar cuidado para não reduzir as diversas situações e atitudes de milhões de mulheres muçulmanas para uma única peça de roupa. Talvez seja hora de desistir da obsessão americana com o véu e focar em questões mais sérias com as quais as feministas e outras deveriam de fato estar preocupadas.

Por último, o significante problema político-ético que a burca levanta é como lidar com os "outros" culturais. Como devemos lidar com a diferença sem aceitar a passividade assumida pelo relativismo cultural pelo qual os antropólogos são famosos - um relativismo que diz que é a cultura deles e que não é da minha conta julgar ou interferir, apenas tentar entender. O relativismo cultural é certamente uma melhora em relação ao etnocentrismo e ao racismo, ao imperialismo cultural e à imperiosidade intrínseca a ele; o problema é que é muito tarde para interferir. As formas de vidas que encontramos ao redor do mundo já são produtos de longas histórias de interações.

Eu quero explorar as questões da mulher e do relativismo cultural e os problemas da "diferença" a partir de três ângulos. Primeiro, eu quero considerar o que antropólogas feministas (aquelas presas àquela relação inconveniente, como Strathern ${ }^{14}$ afirmou) farão em relação às alianças políticas estranhas. Eu costumava me sentir dividida quando recebia por e-mail as petições que circularam ao longo dos últimos anos em defesa das mulheres afegãs sob o regime do Talibã. Eu não era a favor do dogmatismo do Talibã. Eu não apoio a opressão das mulheres. Mas a proveniência da campanha me preocupava. Eu não costumo me ver na companhia política de celebridades de Hollywood. ${ }^{15}$ Eu nunca tinha recebido uma petição de tais mulheres defendendo o direito das mulheres palestinas à segurança contra os bombardeios israelenses ou perseguição diária nos pontos de fiscalização das estradas, pedindo aos Estados Unidos que reconsiderassem seu apoio a governos que as expropriaram, as privaram do trabalho e dos direitos de cidadãs, e lhes negaram as mais básicas liberdades. Talvez algumas dessas mesmas pessoas possam estar assinando petições para salvar as mulheres africanas da mutilação genital ou mulheres indianas da morte pelo dote. Entretanto, eu não acho que seria igualmente fácil mobilizar tantas dessas mulheres americanas e europeias se não fosse um caso de homens muçulmanos oprimindo mulheres muçulmanas - mulheres em relação às quais elas podem sentir pena e se sentir soberbamente superiores. A diva da televisão Oprah Winfrey receberia em seu programa a Women in Black, o grupo pacifista de mulheres de Israel, como fez 
16 GLOBAL EXCHANGE, 2002.

com a Associação Revolucionária das Mulheres do Afeganistão (Rawa), que também recebeu o prêmio de Mulher do Ano da revista Glamour Magazine? O que faremos dos "Reality Tours" pós-Talibã, como o que foi divulgado na internet pela Global Exchange para março de 2002 sob o título: "Coragem e tenacidade: a delegação de uma mulher para o Afeganistão"? A razão para o tour de US\$ 1.400,00 é que, "com a remoção do governo Talibã, as mulheres afegãs, pela primeira vez desde a última década, têm a oportunidade de reclamar seus direitos humanos básicos e estabelecer seu papel como cidadãs iguais por participar na reconstrução da nação". O objetivo do tour, celebrar a Semana Internacional da Mulher, é "desenvolver a percepção dos problemas e questões que as mulheres afegãs estão enfrentando, bem como testemunhar a mudança das condições políticas, econômicas e sociais que criaram novas oportunidades para as mulheres do Afeganistão". ${ }^{16}$

Ser crítico em relação a tal celebração dos direitos das mulheres no Afeganistão não é julgar quaisquer organizações femininas locais, como a Rawa, cujos membros têm trabalhado corajosamente desde 1977 por um Afeganistão democrático e secular no qual os direitos humanos das mulheres sejam respeitados, contra regimes apoiados por soviéticos ou conservadores americanos, sauditas ou paquistaneses. Sua documentação do abuso e seu trabalho por clínicas e escolas têm sido enormemente importantes.

Também não é culpar as campanhas que expuseram as terríveis condições sob as quais o Talibã colocou as mulheres. A campanha Feminist Majority ajudou a pôr fim ao acordo secreto sobre o duto de petróleo entre o Talibã e a multinacional americana Unocal, que seguia contando com o apoio da administração americana. As campanhas feministas ocidentais não devem ser confundidas com as hipocrisias do novo feminismo colonial de um presidente republicano que não foi eleito por sua posição em questões feministas ou de administrações que minimizaram o terrível registro de violações de mulheres pelos aliados dos EUA na Aliança do Norte, como documentado pela Human Rights Watch e pela Anistia Internacional, entre outras. Estupros e ataques eram generalizados no período de lutas internas que devastaram o Afeganistão antes de o Talibã vir para restaurar a ordem.

É, entretanto, sugerir que precisamos olhar de perto o que nós estamos apoiando (e o que não estamos) e pensar cuidadosamente sobre o porquê. Como deveríamos lidar com a complicada política e ética de nos vermos em acordo com aqueles de quem normalmente discordamos? Eu não sei como muitas feministas que se sentiram bem ao salvar 
17 Ver ONG, 1988.

mulheres afegãs do Talibã também estão pedindo por uma redistribuição global da riqueza ou contemplando sacrificar seu próprio consumo radicalmente para que mulheres africanas ou afegãs possam ter alguma chance de possuir o que eu acredito que deveria ser um direito humano universal - 0 direito a estar livre da violência estrutural, da desigualdade global e da devastação da guerra; os direitos diários de ter algo para comer, ter casas onde suas famílias possam viver e prosperar, ter meios de subsistência decentes para que seus filhos possam crescer e ter a força e segurança para trabalhar, dentro de suas comunidades e com quaisquer alianças que desejem, e viver uma boa vida, o que pode muito bem incluir mudar a forma como essas comunidades estão organizadas.

A suspeita acerca dos aliados é apenas o primeiro passo; não vai nos dar uma forma de pensar mais positivamente sobre o que fazer ou como se posicionar. Para tanto, nós precisamos nos confrontar com duas questões maiores. A primeira é a aceitação da possibilidade da diferença. Nós só podemos libertar as mulheres afegãs para serem como nós ou será que devemos reconhecer que, mesmo após a "liberação" em relação ao Talibã, elas possam querer coisas diferentes daquelas que desejaríamos para elas? O que fazer em relação a isso? Segundo, nós precisamos ser vigilantes em torno da retórica de salvar pessoas por conta do que isso implica nossas atitudes.

Novamente, quando eu falo em aceitar a diferença, eu não estou supondo que deveríamos nos resignar a ser relativistas culturais que respeitam o que quer que aconteça em outros lugares como sendo "apenas a cultura deles". Eu já discuti os perigos das explicações "culturais"; as culturas "deles" fazem tanto parte da história e de um mundo interconectado quanto a nossa faz. O que advogo é o trabalho duro envolvido em reconhecer e respeitar as diferenças - precisamente como produtos de diferentes histórias, como expressões de diferentes circunstâncias e como manifestações de desejos diferentemente estruturados. Nós podemos querer a justiça para as mulheres, mas podemos aceitar que pode haver ideias diferentes sobre a justiça e que mulheres diferentes podem querer, ou escolher, futuros diferentes daqueles que vislumbramos como sendo melhores? ${ }^{17}$ Nós precisamos considerar que eles possam ser trazidos para a individualidade, por assim dizer, em uma linguagem diferente.

Relatórios da Conferência de Paz de Bonn, realizada no fim de novembro para discutir a reconstrução do Afeganistão, revelaram diferenças significativas entre as poucas mulheres feministas e as ativistas afegãs presentes. A posição da Rawa foi no sentido de rejeitar qualquer 
${ }^{18}$ Ziba MIR-HOSSEINI, 1999; Haideh MOGHISSI, 1999; e Afsaneh NAJMABADI, 1998 e 2000.

${ }^{19}$ ABU-LUGHOD, 2001. aproximação conciliatória à governança islâmica. De acordo com um relatório que li, a maioria das mulheres ativistas, especialmente aquelas localizadas no Afeganistão que estavam a par das realidades no campo, concordaram que o Islã teria que ser o ponto de partida para a reforma. Fátima Gailani, uma conselheira das delegações nos EUA, teria dito: "Se eu for ao Afeganistão hoje e pedir votos às mulheres pela promessa de trazer-Ihes secularismo, elas me dirão para ir para o inferno". Em vez disso, de acordo com o relatório, a maior parte dessas mulheres buscava em um lugar que pode parecer surpreendente a inspiração sobre como lutar por igualdade. Elas olhavam para o Irã como um país onde viam as mulheres fazendo avanços significativos em um contexto islâmico - em parte através de um movimento feminista orientado pelo Islã que está desafiando as injustiças e reinterpretando a tradição religiosa.

A situação no Irã é, ela mesma, objeto de debate acirrado entre os ciclos feministas, especialmente entre as feministas iranianas no Oeste. ${ }^{18}$ Não é claro se e de que formas as mulheres obtiveram avanços e se o grande crescimento da instrução, a diminuição da taxa de natalidade, a presença de mulheres nas profissões e no governo e um florescimento feminista nos campos culturais como a literatura e o cinema ocorrem por conta, ou apesar, do estabelecimento de uma dita República Islâmica. O conceito de um feminismo islâmico é, ele mesmo, controverso. É ele um oximoro ou se refere a um movimento viável forjado por mulheres corajosas que desejam uma terceira via?

Uma das coisas a respeito das quais devemos ser mais cuidadosos ao pensar nas feministas do Terceiro Mundo e no feminismo em diferentes partes do mundo muçulmano é como não cair em polarizações que colocam o feminismo do lado do Ocidente. Eu escrevi a respeito dos dilemas encarados por feministas árabes quando as feministas ocidentais iniciam campanhas que as tornam vulneráveis a denúncias locais, da parte de conservadores de todos os tipos, quer islâmicos, quer nacionalistas, de serem traidoras. ${ }^{19}$ Tal como alguns semelhantes a Afsaneh Najmabadi argumentam agora, não só é errado ver a história de maneira simplista em termos de uma oposição putativa entre o Islã e - Ocidente (como tem acontecido agora nos EUA e como aconteceu paralelamente no mundo muçulmano), mas também é estrategicamente perigoso aceitar essa oposição cultural entre o Islã e o Ocidente, entre o fundamentalismo e o feminismo, porque aquelas muitas pessoas dentro de países islâmicos que estão tentando encontrar alternativas às injustiças presentes, aquelas que possam querer rejeitar a divisão e misturar diferentes histórias e culturas, que não aceitam que ser feminista significa ser ocidental, estarão 
${ }^{20}$ MAHMOOD, 2001, p. 223.

${ }^{21}$ MAHMOOD, 2001.

sob pressão para escolher, tal como nós estamos: Você está conosco ou está contra nós?

Meu ponto é lembrar-nos de estar atentos às diferenças, de ser respeitosos em relação a outros caminhos que levem à mudança social e que possam trazer às mulheres vidas melhores. Pode haver uma liberação que seja islâmica? E, além disso, será a liberação realmente um objetivo pelo qual todas as mulheres ou o povo se esforçam? Emancipação, igualdade e direitos são parte de uma linguagem universal que nós devemos usar? Citando Saba Mahmood, ao escrever sobre as mulheres no Egito que estão buscando se tornar muçulmanas devotas,

O desejo pela liberdade e liberação é um desejo historicamente situado, cuja força motivacional não pode ser assumida a priori, mas precisa ser reconsiderada à luz de outros desejos, aspirações e capacidades inerentes a um sujeito culturalmente e historicamente localizado. ${ }^{20}$

Em outras palavras, poderiam outros desejos ser mais significativos para diferentes grupos de pessoas? Viver em famílias unidas? Viver próximo de Deus? Viver sem guerra? Eu fiz trabalho de campo no Egito por mais de 20 anos e não consigo pensar em uma única mulher que conheça, da mais pobre na zona rural à mais educada cosmopolita, que tenha de qualquer forma expressado inveja das mulheres norte-americanas, mulheres que elas tendem a perceber como sendo despojadas da comunidade, vulneráveis à violência sexual e exclusão social, dirigidas mais pelo sucesso individual que pela moralidade, ou estranhamente desrespeitosas em relação a Deus.

Mahmood $^{21}$ apontou uma coisa perturbadora que acontece quando alguém discute o respeito por outras tradições. Ela nota que parece haver uma diferença nas demandas políticas feitas àqueles que trabalham ou estão tentando entender os muçulmanos e os islâmicos e àqueles que trabalham em projetos secular-humanitários. Ela, que estuda o movimento de devoção no Egito, é consistentemente pressionada a denunciar todo o mal feito pelos movimentos islâmicos ao redor do mundo - de outra forma, ela é acusada de ser apologista. Mas nunca parece haver demanda paralela para aqueles que estudam o humanismo secular e seus projetos, apesar das terríveis violências que foram associadas a ele através dos últimos dois séculos, de guerras mundiais ao colonialismo, dos genocídios à escravização. Nós precisamos ter tão pouca fé dogmática no humanismo secular quanto no islamismo, e a mesma mente aberta para as possibilidades complexas dos projetos humanos realizados tanto em uma tradição como na outra. 


\section{Para além da retórica da salvação}

Retornemos, finalmente, ao meu título: "As mulheres muçulmanas precisam de salvação?". A discussão da cultura, do uso do véu e de como se pode navegar pelo terreno incerto da diferença cultural deveriam lançar uma luz distinta sobre a autocongratulação de Laura Bush acerca do regozijo das mulheres afegãs liberadas pelas tropas americanas. É profundamente problemático construir a mulher afegã como alguém que precisa de salvação. Quando se salva alguém, assume-se que a pessoa está sendo salva de alguma coisa. Você também a está salvando para alguma coisa. Que violências estão associadas a essa transformação e quais presunções estão sendo feitas sobre a superioridade daquilo para o qual você a está salvando? Projetos de salvar outras mulheres dependem de, e reforçam, um senso de superioridade por parte dos ocidentais, uma forma de arrogância que merece ser desafiada. Tudo o que se precisa fazer para vislumbrar a qualidade condescendente da retórica de salvar mulheres é imaginar utilizá-la hoje nos Estados Unidos em relação a grupos em desvantagem, como mulheres afro-americanas ou mulheres proletárias. Nós agora entendemos que elas sofrem uma violência estrutural. Tornamonos politizados acerca de raça e de classe social, mas não em relação à cultura.

Como antropólogas, feministas ou cidadãs engajadas, deveríamos tomar cuidado ao entrar na pele das cristãs missionárias do século XIX que devotaram suas vidas a salvar suas irmãs muçulmanas. Um dos meus documentos favoritos daquele período é uma coleção chamada Nossas irmãs muçulmanas, os procedimentos de uma conferência de mulheres missionárias realizada no

22 VAN SOMMER E ZWEMMER, 1907.

${ }^{23}$ VAN SOMMER E ZWEMMER, 1907, p. 15.

${ }^{24}$ VAN SOMMER E ZWEMMER, 1907, p. 15.
Cairo, em 1906..$^{22}$ O subtítulo do livro é Um clamor de necessidade das terras da escuridão interpretado por aqueles que o ouviram. Falando sobre ignorância, reclusão, poligamia e uso do véu que afligiam a vida das mulheres no mundo muçulmano, as mulheres missionárias falavam de sua responsabilidade de fazer com que as vozes dessas mulheres fossem ouvidas. Como afirma a introdução, "Elas nunca chorarão por si mesmas, uma vez que estão sob os grilhões de séculos de opressão". ${ }^{23}$ "Este livro", dizem elas, "com sua triste e reiterada história de mal e opressão é uma acusação e um apelo. É um apelo às mulheres cristãs para que consertem esses erros e iluminem essa escuridão com sacrifício e serviço". ${ }^{24}$

Podem-se ouvir inacreditáveis ecos de seus virtuosos objetivos hoje, ainda que a linguagem seja secular, os apelos não a Jesus, mas aos direitos humanos ou ao Ocidente liberal. A contínua aceitação de tal imaginário e 
sentimentos pode ser vista em sua aplicação para causas humanitárias perfeitamente boas. Em fevereiro de 2002, eu recebi um convite para uma recepção em honra de uma rede humanitária internacional chamada Médecins Du Monde (MdM), Doctors of the World. Sob o patrocínio do embaixador francês nos Estados Unidos, do chefe da delegação da União Europeia nas Nações Unidas e de um membro do Parlamento Europeu, o coquetel de recepção promoveria a exibição de fotografias sob o título clichê de Mulheres afegãs: por trás do véu.

O convite foi marcante não apenas pela fotografia colorida de mulheres em burcas esvoaçantes andando pelas montanhas desérticas do Afeganistão, mas também pelo texto, parte do qual cito a seguir.

\begin{abstract}
Por 20 anos, a MdM tem lutado incessantemente para ajudar àqueles que são mais vulneráveis. Mas crescentemente, densos véus cobrem as vítimas da guerra. Quando o Talibã chegou ao poder em 1996, as mulheres afegãs perderam suas faces. Desvendar a face de alguém que recebia tratamento médico era atingir certa intimidade, encontrar um pequeno espaço para uma liberdade secreta e recuperar um pouco da dignidade desse alguém. Em um país onde as mulheres não tinham acesso a tratamento médico por não terem o direito de aparecer em público, onde as mulheres não tinham 0 direito de praticar a medicina, o programa da MdM se manteve persistentemente lembrando os direitos humanos. Por favor, junte-se a nós e ajude a levantar o véu.
\end{abstract}

Apesar de eu não poder começar a abordar aqui as fantasias de intimidade associadas com a retirada do véu, fantasias reminiscentes das obsessões coloniais francesas tão brilhantemente desmascaradas por Alloula em The Colonial Harem (1986), eu posso perguntar por que os projetos humanitários e o discurso dos direitos humanos no século XXI precisam se apoiar em tais construções da mulher muçulmana.

Não poderíamos deixar para trás os véus e as vocações para salvar os outros, e em lugar disso treinar nossa visão para formas de fazer do mundo um lugar mais justo? A razão pela qual o respeito pela diferença não deveria ser confundido com o relativismo cultural é que ele não impede que nos perguntemos como nós, vivendo nesta privilegiada e poderosa parte do mundo, podemos examinar nossas próprias responsabilidades pelas situações em que outros em países distantes se encontram. Nós não estamos fora do mundo, olhando sob a sombra - ou véu - das culturas opressivas; nós somos parte desse mundo. Os próprios movimentos islâmicos surgiram em um mundo moldado pelo 
intenso engajamento das potências ocidentais na vida do Oriente Médio.

Uma aproximação mais produtiva, me parece, seria perguntar como nós poderíamos contribuir para fazer do mundo um lugar mais justo. Um mundo não organizado em torno da estratégia militar e de demandas econômicas; um lugar onde certos tipos de forças e valores que ainda podemos considerar importantes poderiam ter voz e onde há a paz necessária para que discussões, debates e transformações ocorram dentro das comunidades. Nós precisamos nos perguntar quais tipos de condições mundiais poderíamos ajudar a construir, de tal maneira que os desejos populares não serão determinados por um senso imbatível de abandono em face de formas de injustiça global. Ao buscarmos ser ativos nas questões de lugares distantes, podemos fazer isso com o espírito de apoio àqueles dentro de comunidades cujos objetivos são fazer as vidas de mulheres (e homens) melhores (como Walley indagou em relação às práticas de mutilação genital na África, em 1997)? Podemos utilizar uma linguagem igualitária de alianças, coalizões e solidariedade em lugar de uma linguagem de salvação?

Mesmo a Rawa, a agora celebrada Associação Revolucionária das Mulheres do Afeganistão, que foi tão instrumental em trazer à atenção das mulheres dos EUA os excessos do Talibã, se opôs ao bombardeio americano desde o começo. Não veem nisso a salvação das mulheres afegãs, e sim um aumento do sofrimento e da perda. Por muito tempo clamaram pelo desarmamento e por forças de manutenção da paz. Suas porta-vozes apontam para os perigos de se confundirem governos com pessoas, o Talibã com afegãos inocentes que serão mais prejudicados. Consistentemente lembram às audiências que observem atentamente a forma como as políticas estão sendo organizadas em torno de interesses petrolíferos, da indústria armamentista e do comércio internacional de drogas. Não estão obcecadas com o véu, mesmo sendo as feministas mais radicais que têm trabalhado por um Afeganistão secular e democrático.

Infelizmente, apenas as suas mensagens sobre os excessos do Talibã foram ouvidas, apesar de suas críticas contra aqueles no poder no Afeganistão terem incluído regimes anteriores. Um primeiro passo para ouvir sua mensagem mais ampla é romper com a linguagem das culturas alienígenas, quer para compreendê-las ou eliminálas. O trabalho missionário e o feminismo colonial pertencem ao passado. Nossa tarefa é explorar criticamente o que poderíamos fazer para ajudar a criar um mundo no qual aquelas pobres mulheres afegãs, por quem "o coração 
daqueles no mundo civilizado se parte", possam ter segurança e vidas decentes.

\section{Referências}

ABU-LUGHOD, Lila. Veiled Sentiments: Honor and Poetry in a Bedouin Society. Berkeley: University of California Press, 1986.

"Movie Stars and Islamic Moralism in Egypt." Social Text, v. 42, p. 53-67, 1995. . Remaking Women: Feminism and Modernity in the Middle East. Princeton: Princeton University Press, 1998. . "Orientalism and Middle East Feminist Studies." Feminist Studies, v. 27, n. I, p. 101-113, 2001.

AHMED, Leila. Women and Gender in Is/am. New Haven, CT: Yale University Press, 1992.

ALLOULA, Malek. The Colonial Harem. Minneapolis: University of Minnesota Press, 1986.

BRENNER, Suzanne. "Reconstructing Self and Society: Javanese Muslim Women and 'the Veil'." American Ethnologist, v. 23, n. 4, p. 673-697, 1996.

EL GUINDI, Fadwa. Veil: Modesty, Privacy and Resistance. Oxford: Berg, 1999.

FREMSON, Ruth. "Allure Must Be Covered: Individuality Peeks Through." New York Times, p. 4-14, Nov. 2001.

GLOBAL EXCHANGE. Courage and Tenacity: A Women's Delegation to Afghanistan. 2002. Disponível em: <http:// www.globalexchange.org/tours/auto/2002-0305_CourageandTenacityAWomensDele, html>. Acesso em: 10 fev. 2011.

GOLDENBERG, Suzanne. "The Woman Who Stood Up to the Taliban." The Guardian, Jan. 2002. Disponível em: < http:/ /222guardian.co.uk/afghanis tan/story/0,1284,63840>. Acesso em: 10 dez. 2002.

HIRSCHKIND, Charles; MAHMOOD, Saba. "Feminism, the Taliban, and the Politics of Counter-Insurgency." Anthropological Quarterly, v. 75, n. 2, p. 107-122, 2002.

LAZREG, Marnia. The Eloquence of Silence: Algerian Women in Question. New York: Routledge, 1994.

MACLEOD, Arlene. Accommodating Protest. New York: Columbia University Press, 1991.

MAHMOOD, Saba. "Feminist Theory, Embodiment, and the Docile Agent: Some Reflections on the Egyptian Islamic Revival." Cultural Anthropology, v. 16, n. 2, p. 202-235, 2001.

MIR-HOSSEINI, Ziba. Islam and Gender: The Religious Debate in Contemporary Iran. Princeton: Princeton University Press, 1999.

MOGHISSI, Haideh. "Feminism in an Islamic Republic." In: HADDAD, Yvonne; ESPOSITO, John (Ed.). Islam, Gender and 
Social: Change. New York: Oxford University Press, 1998. p. 59-84.

. Feminism and Is/amic Fundamentalism. London: Zed Books, 1999. 2000.

"(Un)Veiling Feminism." Social Text, v. 64, p. 29-15,

ONG, Aihwa. "Colonialism and Modernity: Feminist RePresentations of Women in Non-Western Societies." Inscriptions, v. 3/4, p. 79-93, 1988.

. "State Versus Islam; Malay Families, Women's Bodies, and the Body Politic in Malaysia." American Ethnologist, v. 17, n. 2, p. 258-276, 1990.

PAPANEK, Hanna. "Purdah in Pakistan: Seclusion and Modern Occupations for Women." In: PAPANEK, Hanna; MINAULT, Gail (Ed.). Separate Worlds. Columbus, MO: South Asia Books, 1982. p. 190-216.

SAFIRE, William. "On Language." New York Times Magazine, Oct. 2001.

SPIVAK, Gayatri Chakravorty. "Can the Subaltern Speak?" In: NELSON, Cary; GROSSBERG, Lawrence (Eds.). Marxism and the Interpretation of Culture. Urbana: University of Illinois Press, 1988. p. 271-313.

STRATHERN, Marilyn. "An Awkward Relationship: The Case of Feminism and Anthropology." Signs, v. 12, p. 276-292, 1987.

U.S. GOVERNMENT. Our Moslem Sisters: A Cry of Need from Lands of Darkness. New York: Fleming H, Re veil Co., 1907. . 2002. Disponível em: <http://www.whitehouse.gov/ news/releases/2001/11/20011117>. Acesso em: 10 jan. 2001.

VAN SOMMER, Annie; ZWEMMER, Samuel. Our Moslem Sisters. 4. ed. New York: Revell Company, 1907.

WALLEY, Christine. "Searching for 'Voices': Feminism, Anthropology, and the Global Debate over Female Genital Operations." Cultural Anthropology, v. 12, n. 3, p. 405438, 1997.

[Recebido em 10 de agosto de 2011 e aceito para publicação em 18 de agosto de 2011]

\section{Do Muslim Women really need to be saved? Anthropologic Considerations on the Cultural Relativism and its Others}

Abstract: This article explores the ethics of the current "War on Terrorism", asking whether anthropology, the discipline devoted to understanding and dealing with cultural difference, can provide us with critical purchase on the justifications made for American intervention in Afghanistan in terms of liberating, or saving, Afghan women. I look first at the dangers of reifying culture, apparent in the tendencies to plaster neat cultural icons like the Muslim woman over messy historical and political dynamics. Then, calling attention to the resonances of contemporary 
discourses on equality, freedom, and rights with earlier colonial and missionary rhetoric on Muslim women, I argue that we need to develop, instead, a serious appreciation of differences among women in the world - as products of different histories, expressions of different circumstances, and manifestations of differently structured desires. Further, I argue that rather than seeking to "save" others (with the superiority it implies and the violences it would entail) we might better think in terms of (1) working with them in situations that we recognize as always subject to historical transformation and (2) considering our own larger responsibilities to address the forms of global injustice that are powerful shapers of the worlds in which they find themselves. I develop many of these arguments about the limits of "cultural relativism" through a consideration of the burqa and the many meanings of veiling in the Muslim world.

Key Words: Cultural Relativism; Muslim Women; Afghanistan War; Freedom; Global Injustice; Colonialism. 